\title{
РОЗРОБКА СИСТЕМИ АВТОМАТИЗОВАНОГО ПРОЕКТУВАННЯ ГНУЧКОГО АВТОМАТИЗОВАНОГО ВИРОБНИЦТВА
}

\author{
Пуховський Євген Степанович \\ доктор технічних наук \\ Національний технічний університет України «Київський політехнічний інститут імені Ігоря Сікорського» \\ ORCID: 0000-0001-7843-0922 \\ presto5@bigmir.net
}

Проектування гнучких виробничих систем (ГВС) сучасного багатономенклатурного виробництва зазвичай ведеться на основі загального нормування при використанні укрупнених рекомендацій. При цьому не завжди береться до уваги специфріка та особливості конкретного виробництва. В такому проектуванні найважливішим $\epsilon$ досвід проектувальника, що не завжди базується на сучасних методах оптимізації проектних рішень. Тому надзвичайно актуальною є проблема створення автоматизованих систем проектування при розробці гнучких автоматизованих виробництв (ГАВ), які використовують вартісне обладнання з числовим програмним управлінням (ЧПУ). Розробка автоматизованих систем проектування базується на ідеях системного підходу, які визначають різні цикли процесу: проектування - підготовка виробництва - виробництво. Інформація про проектований об'єкт генерується в процесі розробки проекту різними групами користувачів: дослідниками, проектувальниками, конструкторами, технологами, організаторами виробництва. Багаторівневий, циклічний процес проектування потребує використання такого обсягу інформації, який неможливо переробити без застосування сучасних математичних методів та обчислюваної техніки. Тому надзвичайно важливим є створення систем автоматизованого проектування ГАВ, які відзначаються більшою універсальністю, ефективністю і можливістю розвитку, вдосконалення і адаптації до умов різних підприємств. Такі вимоги послужили базою для створення системи автоматизованого проектування ГВС (САП ГВС), що дозволяє протягом розробки проекту враховувати величезний обсяг інформації в автоматичному циклі. Наукова новизна роботи полягає в розробленні інтегрованої системи автоматизації проектування технології обробки та вибору елементів структур ГВС. При цьому забезпечується інфрормаційна єдність з системою технологічної підготовки виробництва на рівні експлуатації ГВС.

Мета роботи - створення інтегрованої автоматизованої системи проектування технологічних процесів та елементів структури гнучкого автоматизованого виробництва на базі сучасних верстатів з чПу, промислових роботів та систем оснащення.

Ключові слова: проектування, автоматизація, верстат, база даних, алгоритм.

DOI https://doi.org/10.32845/msnau.2021.3.6

Вступ. Створення автоматизованих систем проектування гнучких виробничих систем (САП ГВС) базується на ідеях системного підходу. Цей багаторівневий процес викликає неймовірне збільшення обсягу інформації, що на тлі стиковки потреб різних користувачів не дозволяє повністю забезпечити вимоги промисловості по широкому впровадженню методів автоматизації проектування. У цих умовах необхідно розробка систем, які є більш універсальними, ефективними і здатними до розвитку та адаптації до конкретного виробництва. Основою розробленої САП ГВС є математична модель технологічного проектування ГВС та методи формалізованого проектування її елементів та структур (Pukhovskiy, 2010). Програмний комплекс САП ГВС базується на формалізації проектних процедур, основаних на розробленій теорії автоматизації технологічного проектування (Domoradskij, Leskin, Ponomarev, 1986), на основі якої створюються пакети прикладних програм функціональних підсистем. Структура САП ГВС базується на програмних та інформаційних компонентах, що дозволяє вирішувати задачі різних функціональних підсистем на єдиній інформаційній базі та швидко створювати і розвивати систему технологічної підготовки багатономенклатурного виробництва.

Функціональна структура САП ГВС дозволяє вирішувати задачі проектування елементів ГВС, базуючись на розробці технологічних процесів, тобто постулюється, що технологія завжди має бути первинною. Заперечення цього твердження приводить до суттєвих помилок в проектуванні структури ГВС, збільшення затрат та зниження продуктивності виробництва (Melnikov, Voronenko, 1990). Функціональна інтеграція підсистем здійснюється ще на етапі технологічного проектування, при цьому на вході задаються вихідні дані та концепція задачі, а на виході формуються проектні рішення у вигляді математичної моделі.

Результати дослідженняОсновою створення САП ГВС € схема проектування елементів верстатної системи (ВС) за принципом циклічної стратегії (рис. 1). У відповідності до цієї схеми вибір складових частин ГВС проводиться послідовно або паралельно, окремі задачі потребують циклічної процедури. На етапі аналізу початкового виробництва, коли проводиться відбір даних, роботи ведуться паралельними потоками, тому що вони не впливають одне на одного.

У блоках «проектування елементної технології» та «групування технологічних об'єктів «створюється інфрормація, яка використовується на наступних етапах проектування (Pukhovskiy, 2009). Вибір основного технологічного обладнання (ОТО) передбачає вибір не тільки верстатів з чПУ, а й транспортних засобів, ріжучого, 
допоміжного і вимірювального інструменту, а також системи забезпечення технологічних процесів. Виконання всіх цих процедур вимагає використання даних, одержаних в блоках розробки елементної технології та групування технологічних об'єктів та рішень.

Обговорення. Після визначення структури ГВС, складу основного та допоміжного обладнання приступають до розробки планувальних рішень ГВС. Імітаційне моделювання дозволяє зробити оцінку організаційно-технологічної структури ГВС за критеріями: продуктивності виробництва, термінів обробки деталей, завантаження обладнання, часу його простоїв і таке інше.

У блоці оптимізації приймається рішення про завершення процедури проектування або повернення у блок групування для створення та виконання нової процедури для іншої групи деталей.

Загальна структура САП ГВС показана на рис. 2. Основу САП складають бази даних: «елементної технології», основного технологічного обладнання (ОТО), інструментального оснащення (IO), транспортного обладнання (ТО), технологічного оснащення тощо, а також бази знань, які відображають процедури проектування різних функціональних підсистем на єдиній інформаційній базі, оперативно створювати, нарощувати і удосконалювати систему технологічної підготовки багатономенклатурного виробництва.

САП ГВС виконує функції автоматизованого технологічного проектування структури і робочих елементів ГВС різного рівня автоматизації. Передбачається інформаційна єдність з системою технологічної підготовки виробництва на рівні експлуатації ГВС. Програмний комплекс САП ГВС базується на формалізації проектних процедур, заснованої на розробленій теорії автоматизації технологічного проектування, яка представляє собою інваріантну частину САП ГВС і $€$ тою системно-утворюючою ланкою, на основі якої створюються пакети прикладних програм функціональних підсистем.

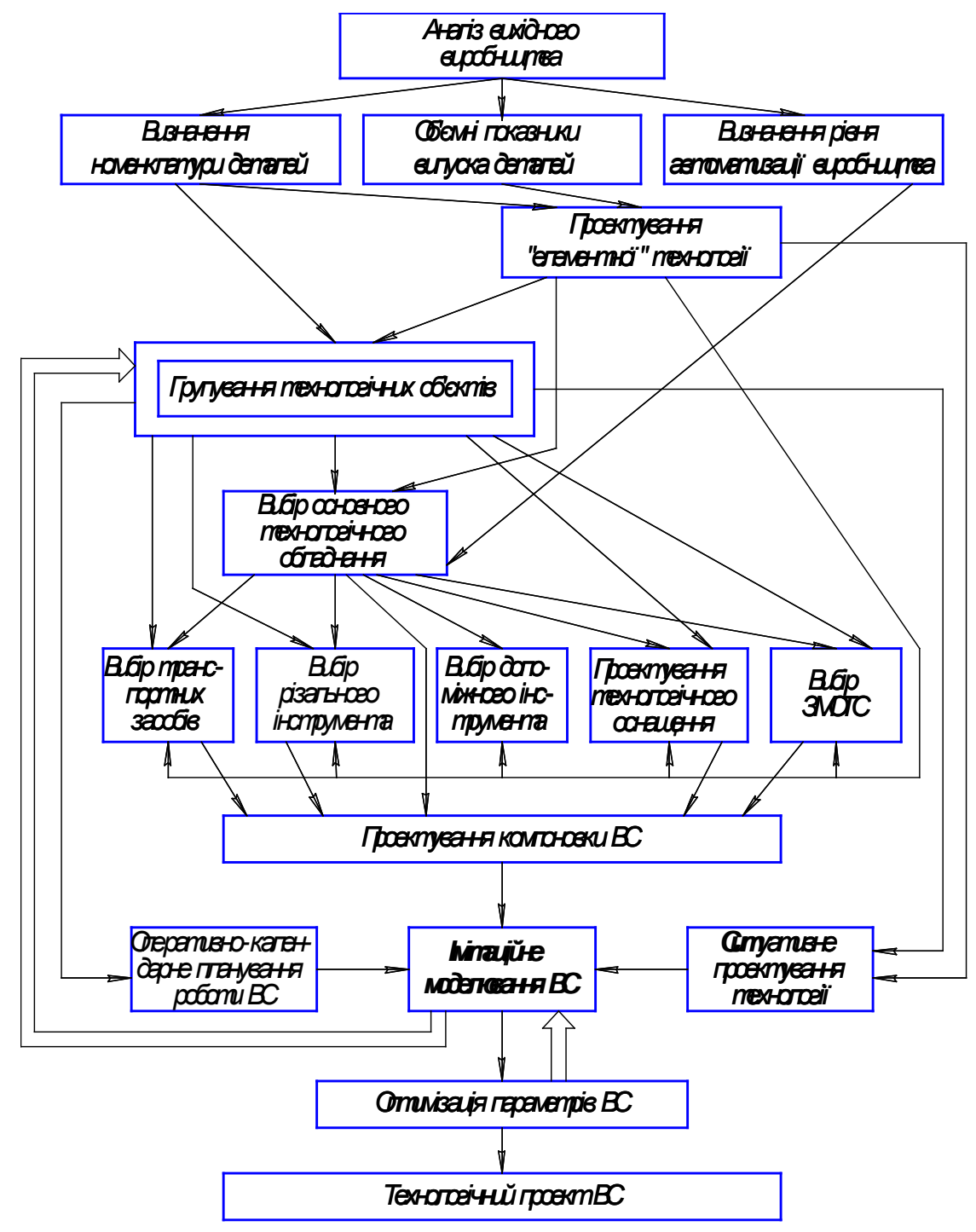

Рис. 1. Схема проектування ГВС багатономенклатурного виробництва за принципом циклічної стратегії 


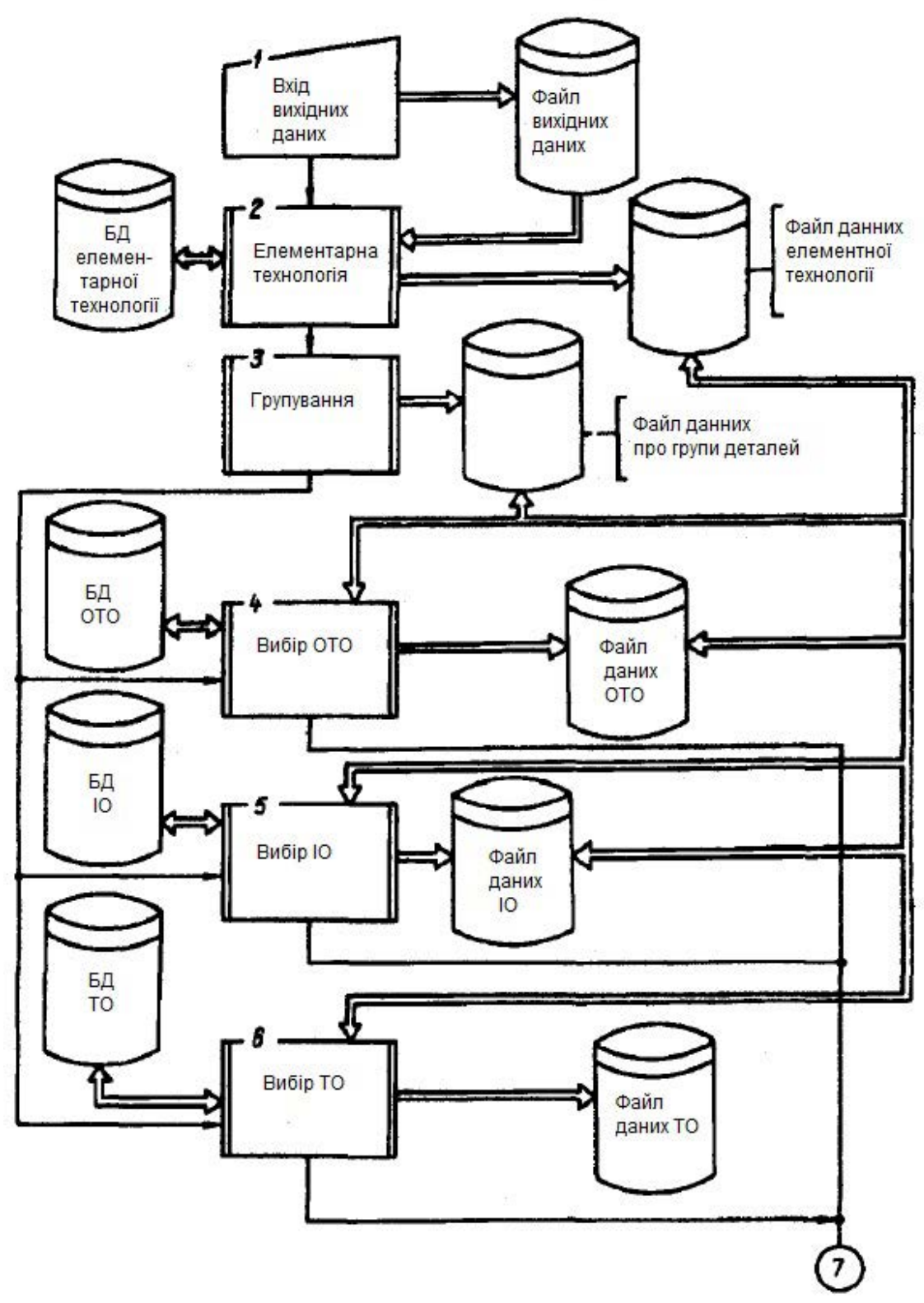

Рис. 2. Загальна структура САП ГВС

Слід зазначити, що циклічна стратегія дозволяє шляхом виконання ітераційних процедур отримати майже оптимальний технологічний проект, який $є$ базою для виконання робочого проекту ГВС.

Головним пу побудові функціональної структури САП ГВС $є$ дослідження інформаційних потоків і зв'язків, які відображають склад і взаємодію окремих підсистем у відповідності до структури задач проектування. При цьому вихідні дані та концепція задачі формуються на вході, а на виході отримуємо проектні рішення. Метод перетворення входу у вихід задається у вигляді математичної моделі. Тут можна задати безліч входів щоб загальна характеристика методу перетворення відповідала класу задач автоматизованого проектування певного типу.

Для ілюстрації процесу координації задач доцільно використовувати трифазні значки (тріади), запозичені з системи структуризації GRISP (Melnikov, Voronenko, 1990).
Функціональна структура (рис. 3) зв'язку завдань і підсистем САП ГВС розроблена на основі структурної декомпозиції завдань проектування ГВС багатономенклатурного виробництва. Процес декомпозиції всієї сукупності завдань завершується на модулі (A1 - A5). Також визначаються зв'язки по інформаційних потоках між модулями та загальні вхід «Вх» і вихід «Вих» (рис. 3).

Структура даних, що використовуються при проектуванні ГВС, дає можливість зробити висновок, що вони можуть бути інтегровані в єдину базу даних САП-ГВС, яка розділяється на системи проектно-орієнтованих і проектно-незалежних даних. У процесі проектування ГВС здійснюється накопичення проміжної інформації окремими підсистемами, яка зберігається у вигляді спеціалізованих файлів змінної інформації інтегрованої бази даних.

Основою функціональної структури САП ГВС є специфіка багатономенклатурного виробництва, що відпо- 


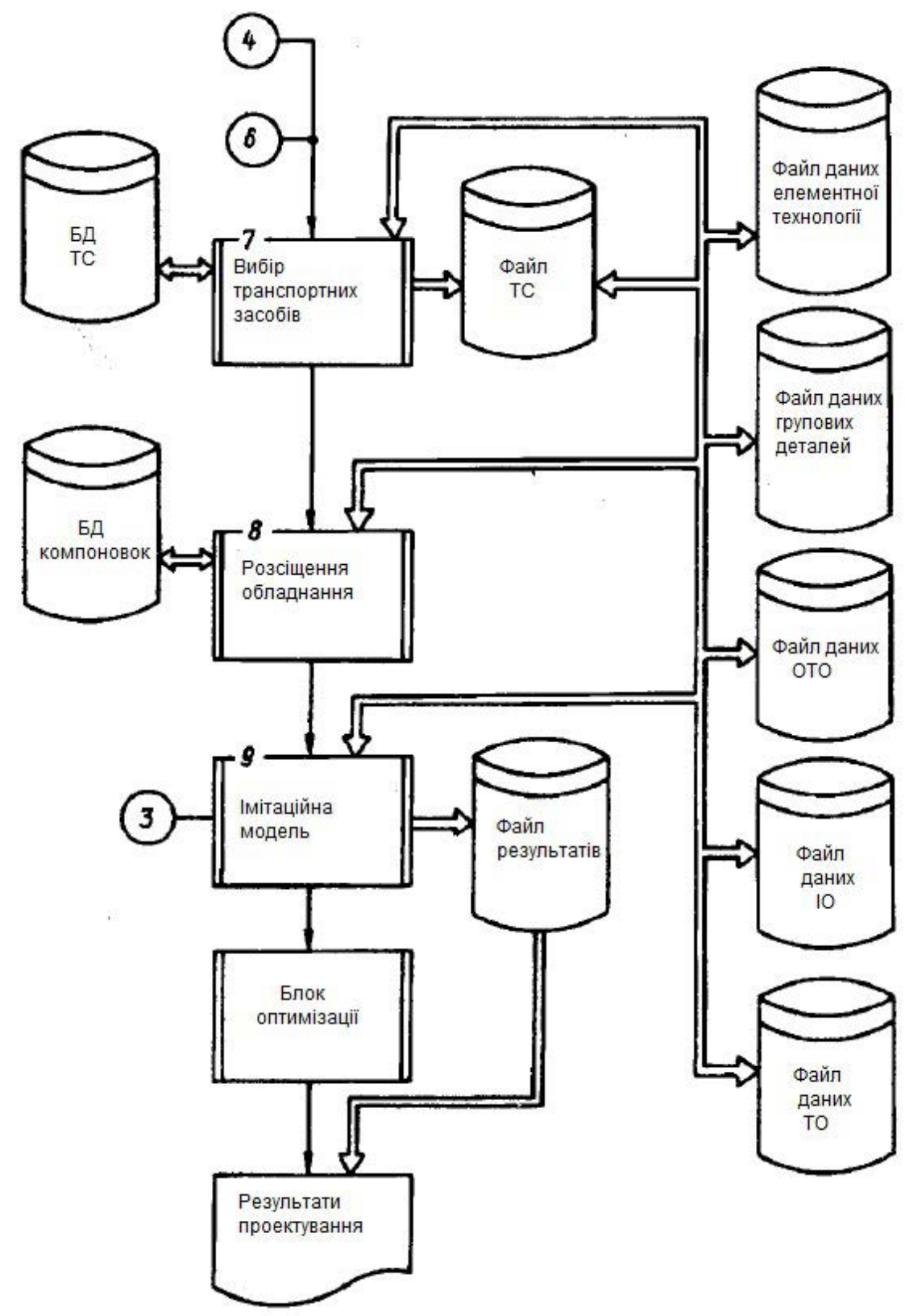

Рис. 2. (Продовження). Загальна структура САП ГВС

відає проблемам уніфікації і стандартизації технологічних об'єктів, використання методів групової технології з урахуванням технологічних властивостей обладнання і оснастки, моделювання та оптимізації проектних рішень (Bazrov, 2001). Функціональна структура САП ГВС побудована з урахуванням логіки взаємодії функціональних підсистем на різних етапах проектування.

Вихідна інформація накопичується в модулі A1 (рис. 3), до складу якого входить САПР «елементної» технології, що поставляє інфрормацію про тимчасові характеристики технологічних процесів в модулі А2 - A5. Характеристики номенклатури деталей зберігаються також і в модулі А2, в якому формуються групові технологічні рішення, що застосовуються потім в модулях АЗ i A4 при проектуванні структури ГВС і засобів технологічного оснащення. Інформація про одержані варіанти ГВС поступає в модуль А5 симуляції та оптимізації проектних рішень. При одержанні неприйнятних результатів проектування в блоці А2 формуються нові дані про склад груп деталей і процес проектування циклічно повторюється, поки не буде отриманий прийнятний результату з точки зору проектувальника. Проектування ГВС вимагає накопичення проміжної інформації, отриманої окремими підсистемами, яка зберігається у вигляді спеціалізованих файлів змінної інформації інтегрованої бази даних (Avramtchuk, Vavilov, 1988).

Організаційною основою фрункціональної структури САП ГВС є особливості побудови багатономенклатурного виробництва, які базуються на уніфікації і стандартизації технологічних об'єктів, застосуванні методів групової технології, прийнятті проектних рішень з урахуванням технологічних властивостей застосовуваного обладнання і оснастки, 
моделюванні та оптимізації проектних рішень (Solomentzev, Mitrofanov, Pavlov, Ribakov, 1989). Технологічні властивості групи деталей визначають структурні елементи ГВС і через динамічні характеристики верстатів впливають на експлуатаційні показники ГВС: продуктивність, коефіцієнти завантаження, використання і змінності устаткування, простої устаткування, обсяг незавершеного виробництва і т. п. (Solomentzev, Sosonkin, 1988; Welch, Emang, 1982).

Планово-компонувальні рішення ГВС залежать від типу, матеріалу і габаритних розмірів деталі, а також від маршруту та терміну її обробки. На компоновку ГВС впливають планово-організаційні властивості групи деталей, які в свою чергу визначають порядок розташування верстатів в ГВС, маршрути матеріальних і транспортних потоків, а також об'ємні показники ГВС - кількість основного, транспортного та допоміжного обладнання. Властивості технологічного обладнання дозволяють при оцінці варіантів структур ГВС виконувати перевірочні проектні процедури по однорідності (гомогенності) верстатного парку системи (ділянки, цеху, заводу). При цьому звертають увагу на властивості масиву верстатного обладнання з урахуванням того, що технологічні характеристики деталей були використані на більш ранніх етапах проектування. Крім того, можуть бути досліджені властивості верстатного, транспортного обладнання, оснащення та інструменту.

Поєднання програмних компонент на єдиній інформаційній базі - основа ефрективного впровадження САП ГВС в умовах виробництв різного типу. Тому особливе місце в САП ГВС займає програмне забезпечення, яке представлено сукупністю програмних засобів, необхідних для реалізації функцій автоматизованого проектування і рішення всіх задач функціональних підсистем (Domoradskij, Leskin, Ponomarev, 1986; Avramtchuk, Vavilov, 1988).

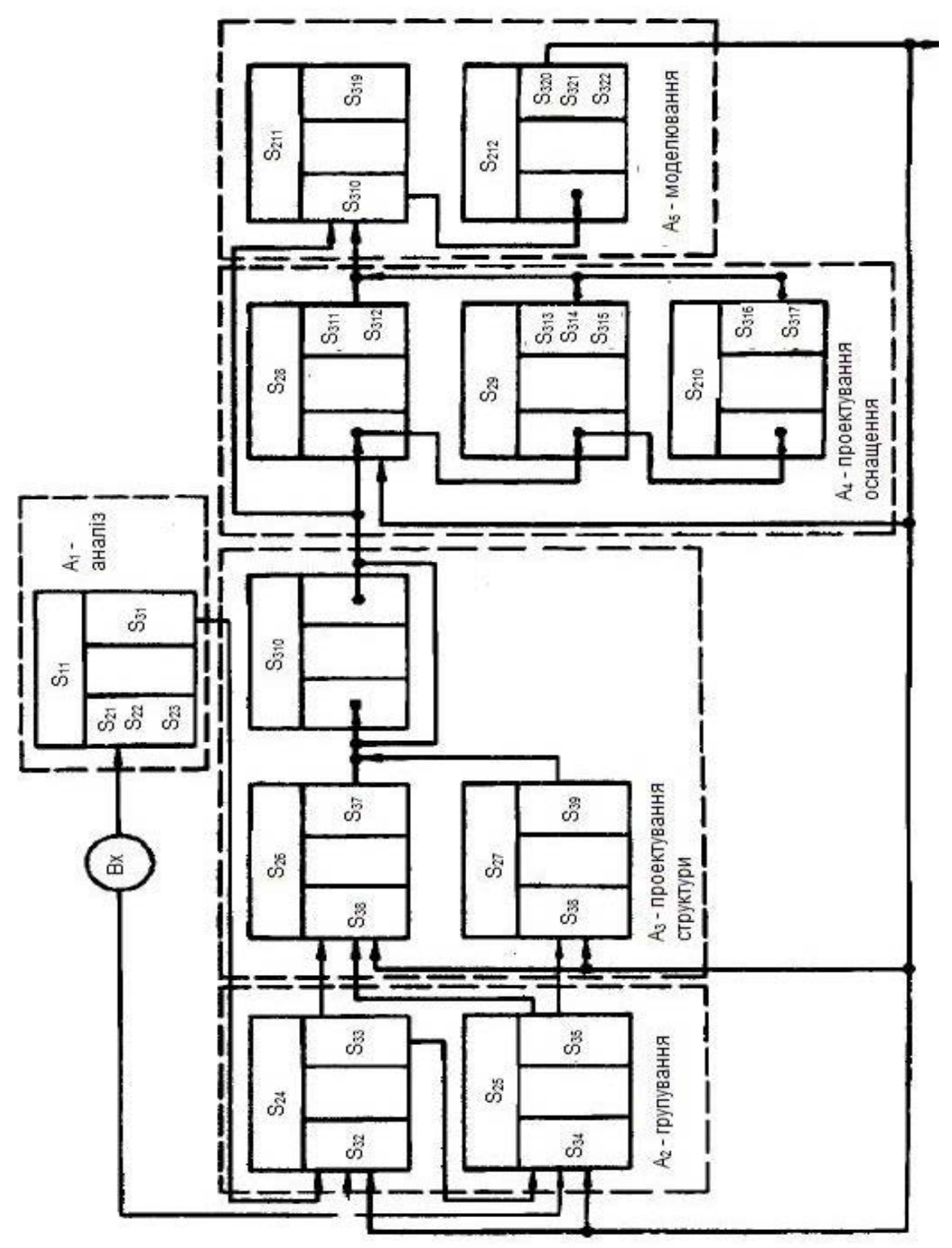

Рис. 3. Функціональна структура взаємозв'язку завдань і підсистем проектування гнучкої системи 
Програмне забезпечення САП ГВС складається з програмного комплексу банків даних, який реалізує інтерактивний режим 3 користувачем і реляційної моделі даних, що забезпечує єдність інформаційної бази засобами опису логічних структур і їх проектування на фрізичні файли. Обчислювальні засоби дозволяють автоматизувати процес генерації програмних модулів, наприклад, програмування діалогових процедур. Можливості інструментальних засобів характеризуються рівнем використовуваного лінгвістичного забезпечення.

Проектні завдання в САП ГВС вирішуються методом реляційної організації баз даних, запропонованим Коддом (Codd, 1970). У цьому методі дані подаються у вигляді незалежного від програмних модулів набору файлів, що дає можливість застосувати набір реляційних процедур обробки інформації. Реляційна база САП ГВС використовує такі принципи: мінімізація структури реквізитів у файлах; комбінація реквізитів не повинна повторюватися в різних файлах бази; пов'язані між собою бази повинні бути фрізично поміщені на носіях з урахуванням можливості їх одночасної роботи користувача з базою; логічна структура бази повинна будуватися на єдиному формалізованому поданні до програмної системи, що дозволяє виконувати наступні процедури: логічна вибірка записів з файлу бази; злиття, множення, перетин, з'єднання, різницю, об'єднання, поділ і стиснення баз; вивід підсумків; сортування; групова вибірка.

Логічна структура бази даних технологічного призначення наведена на рис. 4.

Файл «DETAL» містить інформацію про конструкторські дані деталі та її код. Файли «FRM» і «GEO» відображають форму і геометричні взаємозв'язки всіх поверхонь. У файлі «POW» розташовується класифікатор поверхонь, у файлі «PER» - класифікатор переходів. Використовувані при проектуванні оснащення схеми базування записані у файлі «BAZ». Файли «OB», «RI», «Il», «W I» містять відомості про обладнання, ріжучий, вимірювальний і допоміжний інструмент. Файл «PRIS» містить дані про базові, настановні і затискні елементи пристосувань. Файли «TS» $\mathrm{i}$ «ROB» містять дані про транспортні засоби та промислові роботи. Вихідний фрайл «GRUP» містить інформацію про номенклатуру деталей, яка розділена на групи, для якої проектується ГВС.

Програмне забезпечення САП ГВС, побудоване на методах структурного програмування, дозволило створення програмних модулів: головного модуля ініціалізації комплексу та ідентифікації користувача; головного монітора; монітора для управління процесів актуалізації, зміни баз даних; редакторів баз даних; програми функціональних підсистем САП ГВС.

Головний модуль видає відеограму - заставку САП ГВС і робить запит відомостей про користувача. Ці відомості перевіряються в довіднику користувачів.

Головний монітор САП ГВС показує основне меню і дає можливість проектувальнику увійти в одну з функціональних підсистем (рис. 5). Монітор для управління процесом актуалізації та зміни баз даних забезпечує можливість роботи з будь-яким фрайлом бази даних і функціональних підсистем. Редактор розробляється для кожної бази окремо, що викликано специфікою реквізитного складу і логіки пошуку , верифікації і представлення на екрані інформації з файлів.

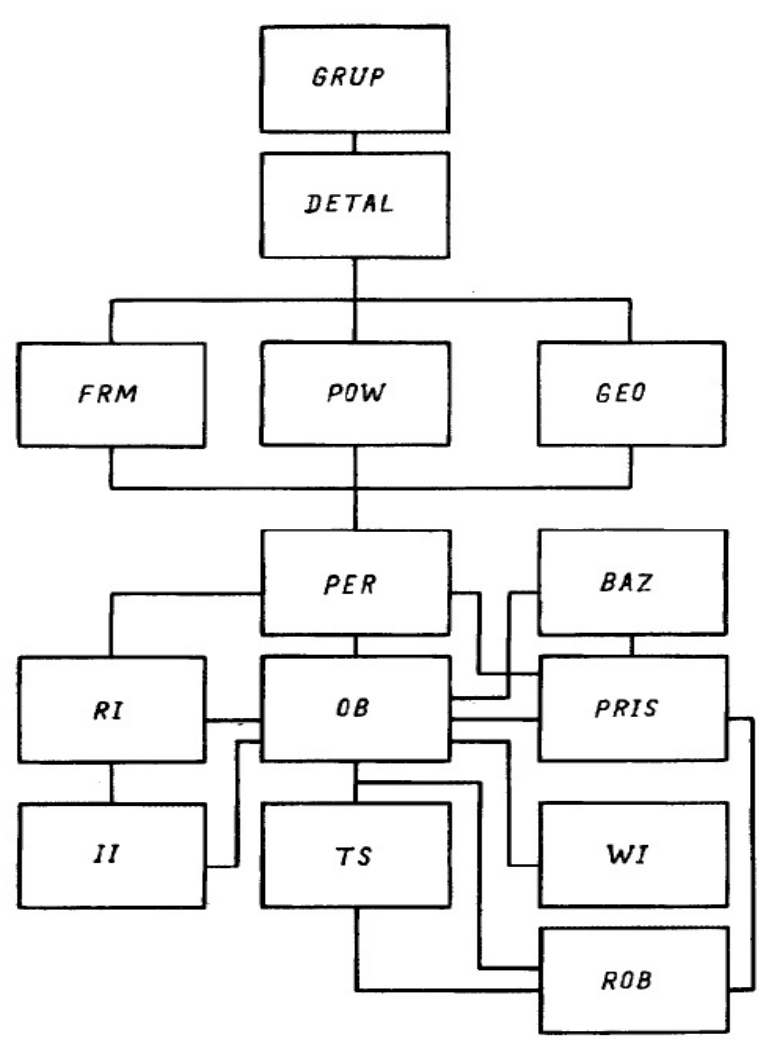

Рис. 4. Логічна структура бази даних

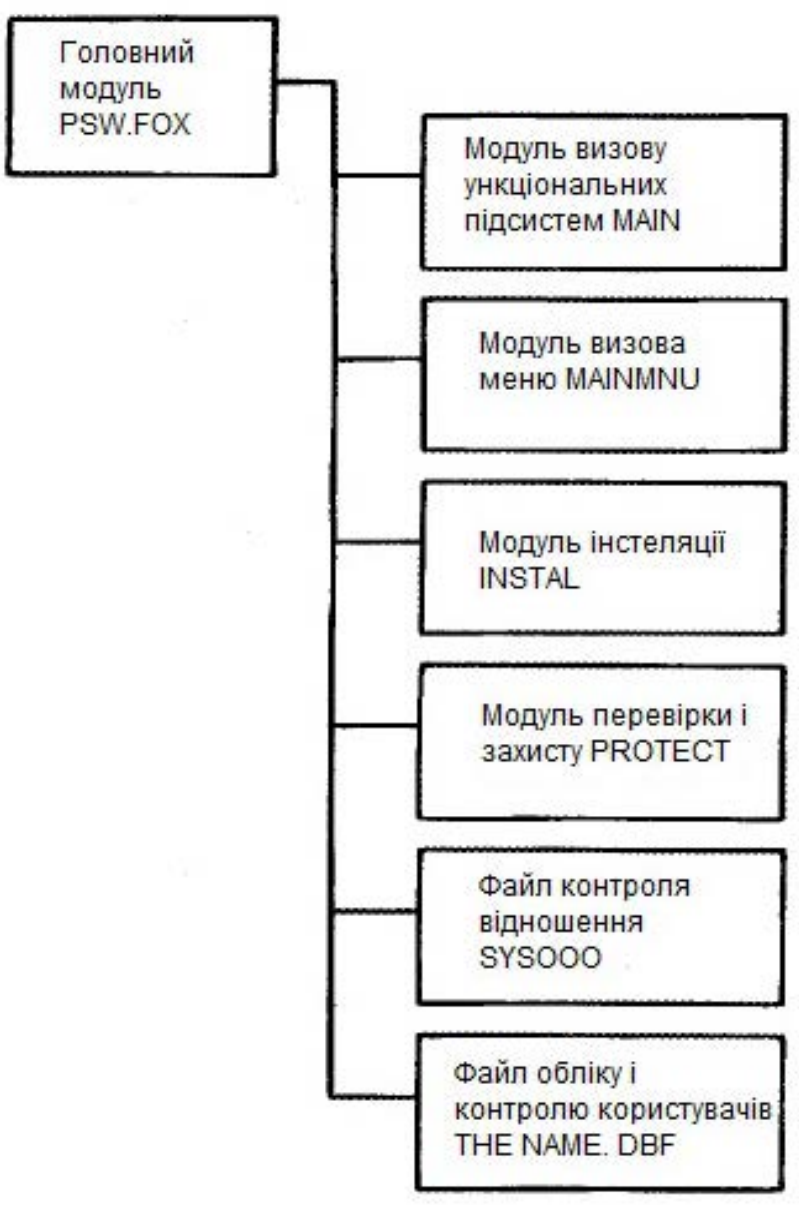

Рис. 5. Структура монітора САП ГВС 
Монітор комплексу програмних засобів САП ГВС $€$ автономною підсистемою, пов'язаною з усіма елементами САП ГВС. При допомозі монітора вирішуються в автоматизованому режимі наступні завдання: інсталяція програмного забезпечення САП ГВС; перевірка відповідності версії комплексу на коректність інсталяції; реєстрація користувачів комплексу програм, встановлення паролів і кодів доступу; виклик і взаємозв'язок функціональних підсистем з базою даних технологічного призначення. Використовувані засоби захисту програмних модулів функціональних підсистем, орієнтовані на роботу під керуванням монітора і окремо від нього не працездатні.

Функціональне меню системи проводить перевірку можливості виходу на завдання підсистем САП ГВС. Структура монітора САП приведена на рис. 5. Головний модуль PSW. FOX забезпечує захист від несанкціонованого доступу і рівня доступу. Модулі MAIN і MAINMNU перевіряють захист установки САП-ГВС в непереміщуваному файлі PASSWORD. FOX. Модуль INSTAL підключає PROTECT з ключем інсталяції, який в свою чергу ствоpює PASSWORD.FOX. Без ключа PROTECT перевіряє PASSWORD.FOX і створює фрайл SYSO00. Облік і контроль користувачів проводиться в фрайлі THENAME. DBF.

Монітор САП ГВС забезпечує режим адміністратора системи, який може змінити користувачів та процес інсталяції системи. Завдання в функціональних підсистемах вибирається після натискання клавіші «Введення». Кожна функціональна задача працює під керуванням власного меню.

Експлуатація САП ГВС в умовах конкретного виробництва передбачає актуалізацію інформації в базі даних технологічного призначення. Особливу увагу при цьому необхідно приділити відповідності ключових реквізитів в різних базах даних. Монітор і функціональні підсистеми САП ГВС працюють в діалоговому режимі.

Програмне забезпечення бази даних забезпечує наступні режими: перегляд, коригування або доповнення полів запису бази даних, упаковка, видалення і пошук по заданому логічному ключу.

При експлуатації САП ГВС база даних технологічного призначення постійно доповнюється і коригується даними про елементи ГВС. Поточний стан бази даних може бути збережений шляхом копіювання підкаталогу DBS. Дані копіюються в розділ з ім'ям ARHddmm, де ARH - приставка найменування архівного розділу, ddmm - дата створення копії в форматі день - місяць. Таким чином можна створити тільки одну копію БД на конкретну дату. При спробі створення копії з уже існуючою датою старі дані будуть загублені. Рекомендується виконувати копіювання бази даних САП ГВС при кожній значній зміні інформації.

Висновки. Розроблена інтегрована система автоматизованого проектування ГВС, яка дозволяє на базі циклічної стратегії проектувати технологічні процеси обробки деталей та синтезувати елементи структури ГВС: основне технологічне обладнання, транспортні засоби, склад систем інструментального та технологічного оснащення. Функціонування такої системи побудовано на використанні величезного обсягу даних про технологію обробки деталей та про засоби виробництва. Тому для роботи САП ГВС повинні бути залучені бази даних та бази знань всієї технології машинобудування та суміжних галузей. Інтегрована система дозволяє автоматизувати безліч проектних процедур, що є вкрай необхідним при створенні сучасного багатономенклатурного виробництва.

\section{Бібліографічні посилання:}

1. Bazrov, B.M. Modulnaja technologija v mashinostroenii. [Modular technology in machine-building]. M., Mashinostroenie, 2001. 368 s. [in Russian].

2. Melnikov, G.N., Voronenko V.P. Proektirovanie mekhanosborochnikh tzekhov . [Design of mechanical assembly shops.]. M., Mashnostroenie, 1990. 352 s. [in Russian].

3. Pukhovskiy, E.S. Proektuvannja tekhnologichnikh protzesiv v umovakh gnuchkogo avtomatizovanogo virobnitztva. [Design of technological processes in conditions of flexible automated production]. Visnik NTUU KPI, Mashinobuduvannja, vip. 59, 2010, s. 267-27. [in Ukrainian].

4. Pukhovskiy, E.S. Problemi grupirovanija detalej pri sozdanii GPS. [ Problems of grouping parts when creating GPS]. Visnik NTUU KPI, Mashinobuduvannja, 2009, s.14-20. [in Russian].

5. Domoradskij, A.N., Leskin A.A., Ponomarev V.M. Sistemnoe proektirovanie integrirovanikh proizvodstvennikh kompleksov. [Systematically projected integrated prozvodstvennyh complexes]. L. Mashinostroenie, 1986. 319 s. [in Russian].

6. Solomentzev, J.M., Sosonkin V.L. Upravlenie gibkimi proizvodstvennimi sistemami. [Manage flexible production systems]. M., Mashinostroenie, 1988, 352 s. [in Russian].

7. Solomentzev, J.M., Mitrofanov V.G., Pavlov V.V., Ribakov L.V. Informatzionno-vichislitelnie sistemi v mashinostroenii. GALS - tekhnologii. [Information and computing systems in mechanical engineering. GALS - technologies]. M., Nauka, 1989, 292 s. [in Russian].

8. Avramchuk E.F., Vavilov F.F., Emelianov S.V. Tekhnologija sistemnogo modelirovanija. [System Modeling Technology]. M., Mashinostroenie, Berlin, Tekhnik. 1988, 520 s. [in Russian].

9. Codd E.F. A relational model of data for large shared banks. Coom. ACM, 1970, H. 6. p. 377-387.

10. elch A., Emang J.T. Group technology, the heart of flexible manufacturing system. Brighton/ U.K., 1982. okt. p. $121-130$.

Pukhovskyy Ye. S., Doctor of Technical Sciences, National Technical University of Ukraine "Igor Sikorsky Kyiv Polytechnic Institute", Kyiv, Ukraine

Development of an automated design system for flexible automated production

Design of flexible manufacturing systems (FMS) of modern multi-level production is usually carried out on the basis of general rationing when using large recommendations. At the same time, the specifics and features of a particular production are not always taken into account. In such a design, the most important is the experience of the designer, which 
is not always based on modern methods of optimizing project solutions. Therefore, the problem of creating automated design systems in the development of flexible automated productions (FAP), which use cost equipment with numerical control (CNC) is extremely urgent. The development of automated design systems is based on the ideas of a systematic approach that determine different cycles of the process: design - production preparation - production. Information about the projected object is generated in the process of project development by different groups of users: researchers, designers, designers, technologists, production organizers. A multilevel, cyclical design process requires the use of such a volume of information that cannot be processed without the use of modern mathematical methods and calculated equipment. Therefore, it is extremely important to create automated gap design systems, which are marked by greater versatility, efficiency and possibility of development, improvement and adaptation to the conditions of various enterprises. Such requirements served as the basis for the creation of an automated design system, which allows to take into account a huge amount of information in the automatic cycle during the development of the project. The scientific novelty of the work is the development of an integrated automation system for the design of processing technology and the selection of elements of FMS structures. At the same time, information unity with the system of technological training of production at the level of operation of FMS is ensured.

The purpose of the work. Creation of an integrated automated system for the design of technological processes and elements of the structure of flexible automated production on the basis of modern CNC machines, industrial robots and equipment systems.

Key words: Design, automation, machine tool, database, algorithm. 